\title{
Multiple Intraosseous Lipoma: Report of Three Cases
}

\author{
A. Murat KALENDER ${ }^{1}$, Fuat OZKAN $^{2}$, Hamide SAYAR ${ }^{3}$, \\ Mustafa USLU ${ }^{4}$, Ahmet $\mathbf{U N}^{5}$ \\ ${ }^{1}$ Kahramanmaras Sutcu Imam University Faculty of Medicine, Department of Orthopedics and Traumatology, \\ Kahramanmaras \\ ${ }^{2}$ Kahramanmaras Sutcu Imam University Faculty of Medicine, Department of Radiodiagnostic, Kahramanmaras \\ ${ }^{3}$ Kahramanmaras Sutcu Imam University Faculty of Medicine, Department of Pathology, Kahramanmaras \\ ${ }^{4}$ Duzce University Faculty of Medicine, Department of Orthopedics and Traumatology, Duzce \\ ${ }^{5}$ OSM Ortadogu Hospital, Department of Orthopedics and Traumatology, Sanliurfa, TURKEY
}

\begin{abstract}
Multiple intraosseous lipoma (MIOL) is extremely rare bone tumour. Its real incidence is estimated as much more because of most of these tumours is asymptomatic and undiagnosed. We reported $3 \mathrm{MIOL}$ patients involving both upper and lower extremity. Two female patient with 30 and 26 age and one male with 52 years old represented by intraosseous lipomatous lesions involving bilateral wrist and hand bones, distal radius, proximal and distal femur, patella, proximal and distal tibia metaphyses, distal fibula, ankle and foot bones. Painful lesions were curetted and grafted by allograft. A distal radius fracture is treated by closed reduction and percutaneus pining. All the lesions healed that is managed by surgery. The asymptomatic lesions were not treated anyway. MIOL needs surgery in the case of pain, pathologic fracture, pathologic diagnosis confirmation and impending fracture. The malign transformation potential is present even rare. It must be followed in long period and carefully. CT is a good diagnostic imaging allowing negative density measurement in lesions between -60 and $-110 \mathrm{HU}$.
\end{abstract}

Keywords: Intraosseous lipomatosis

\section{ÖZET}

\section{Multipl İntraosseoz Lipoma: Üç Olgu Sunumu}

Multipl intraosseoz lipoma (MiOL) kemik tümörleri içinde çok nadir bir tümördür. Ancak gerçek insidansı asemptomatik olduğu ve tanı konulmadan kaldığı için daha yüksek olduğu tahmin edilmektedir. Bu tümörün multipl kemik tutulumu literatürde çok nadir olarak bildirilmiştir. Biz hem üst hem alt ekstremiteyi ilgilendiren 3 vaka sunduk. Otuz ve 26 yaşında 2 kadın ve 52 yaşında erkek hastada her iki el bilek, distal radius, falankslar, karpal ve metakarpal kemikler, femur proksimal, femur distal metafizleri, patella, proksimal ve distal tibia metafizleri, fibula distali, ayak bileği ve ayak kemiklerinin tümünü tutulduğu multipıl intraosseoz lipoma vakası sunuldu. Vakalarda ağıı yapan lezyonlar küretaj ve allogreft greftleme ile tedavi edildi. Radius distalinde kırık gelişen bir hastada kapalı redüksiyon perkutan pinleme uygulandı. Müdahale edilen bütün lezyonlarda düzelme izlendi. Semptom vermeyen lezyonlara tedavi uygulanmadı.

MiOL lezyonları klasik intraosseoz lipomlar gibi yalnızca semptom veren lezyonlarda, kırık tehdidi olan durumlarda veya tanı amaçlı cerrahi müdahaleye intiyaç duyarlar. Çok nadir de olsa malignite gelişim riski mevcuttur. Hastaların uzun sureli takibi gerekir. Bilgisayarlı tomografi (BT) ile lezyon içi densite ölçümünde negatif değer (-60, -110 HU) tanı koydurucudur.

Anahtar Kelimeler: Intraosseos lipomatozis 


\section{INTRODUCTION}

Intraosseous lipomas (IOL) have been considered as $0.1 \%$ of bone tumours. The real incidence has been accepted much greater than previously thought, because of lipomas that are generally asymptomatic and remain undiagnosed. Hypotheses have been range from primary benign neoplasm to reactive bone lesion following trauma or bone infarction. ${ }^{1}$ The intertrochanteric and subtrochanteric regions of the femur and calcaneus have been reported as common sites for this type tumour. The largest case studies of intraosseous lipomas were performed by Milgram ${ }^{2}$, Campbell et al. ${ }^{3}$ and Kapukaya et al. ${ }^{4}$

Intraosseous lipomas are almost always solitary lesions. Multiple bony involvements are extremely rare. There have been only a few case reports in the literature of multiple intra osseous lipomas (MIOL)..$^{5-7}$

Herein, we report 3 cases with MIOL involving the lower and upper extremity. This presentation is extremely unusual for this type of tumour both in terms of involvement and localization. As the patient was symptomatic with extensive pain, limping and fracture, we treated the patient by curettage and bone grafting.

\section{CASE REPORTS}

\section{Case 1:}

A 30-year-old female patient (BB) presented to our clinic with pain in the left ankle. She had this complain for 6 months. Her pain had intensified in the last two months, particularly during performance activities such as stair climbing. She did not have a history of prior ankle pain, operation or any trauma.

She was walking with a limp, but she had a normal range of motion in the hip and knee. The left ankle region especially talus and calcaneus were sensitive to deep palpation. There were no additional physical examination findings such as oedema, hyperaemia or swelling. Her whole blood count and routine blood tests, including the sedimentation, lipid-cholesterol levels and CRP were normal. There was no history of corticosteroid or any hormone usage. Her two plane x-rays revealed a wide cystic cavity with a lytic appearance causing cortical expansion in the left talus, calcaneus, phalanxes, tar-

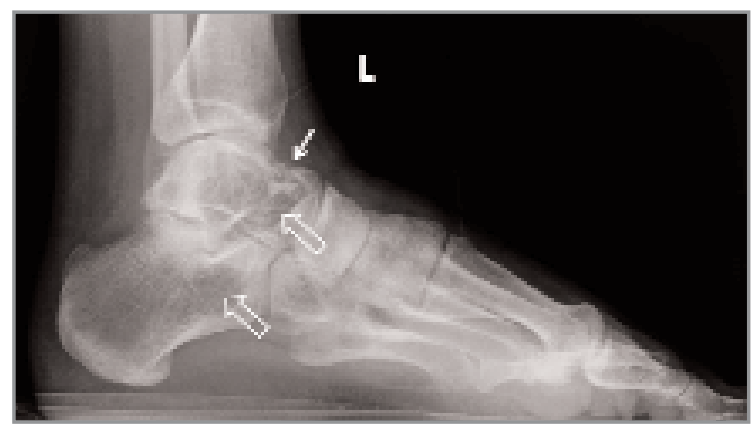

Figure 1. Lateral radiograph of foot shows lucent lesions (open arrows) in talus and calcaneus. Calcaneal lesion has residual trabeculations. It also reveals irregular contour in the dorsal aspect of anterior talus (arrow).

sal and metatarsal bones (Figure 1). There were occasional calcification and sclerosis around these lesions.

Radionuclide bone scan (20 mCi Tc-MDP) was revealed increased activity in both ankle and feet (left is more prominent), both knee region (distal femurs, patella and proximal tibia), both wrist region and hands (including distal radius) and both proximal femur and humerus.

A MRI of left ankle was obtained, which revealed an approximately $2 \times 3 \mathrm{~cm}$ mass with intramedullary localization at talus, $2.5 \times 2 \mathrm{~cm}$ in calcaneus, various dimensions in tarsal, metatarsal bones and phalanxes. The masses had been expanded the cortexes and seemed hyperintense in the T1 -A and T2-A sequences and suppressed in the STIR sequence. A thin circumferential rim of low signal intensity showed sclerotic margin of the fatty lesions on T1-weighted imaging.

Well-marginated and low-density lesions were detected on CT $(-60-110 \mathrm{H})$. Bony trabeculations were absent within the lesions and there was no evidence of fracture. The regional cortex displayed no evidence of thinning. In some areas such as at the left talus, tibial plateau (Figure 2a,b,c,d), distal radius and phalanxes the cortex were thinned and the bone expanded, but elsewhere, as in the proximal tibial metaphysis and calcaneus, the lipomatous areas appeared to be surrounded by a reactive sclerotic margin of rearranged and coarsened trabeculae. Open biopsy, curettage and grafting were planned for differential diagnosis and treatment. Only pain- 


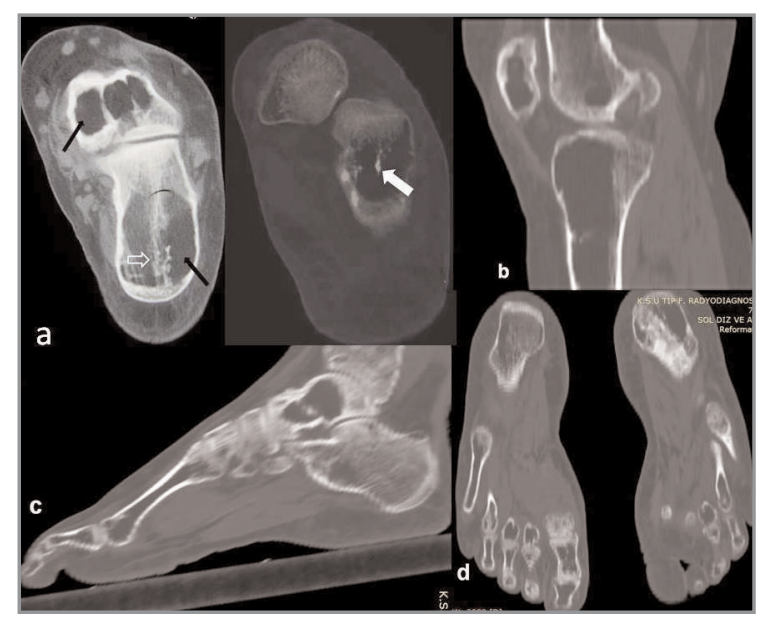

Figure 2 (a). 50 year old woman with stage 2 intraosseous lipoma confirmed histologically with curettage. Axial CT scan reveals lesions of primarily fat attenuation (approximately -85 $\mathrm{HU})$ (black arrows) in anterior of talus and calcaneus with internal calcification (white arrow). Lesions have residual trabeculations (open arrow). (b) Axial and reformatted CT images show stage 1 intraosseous lipomas in femur, tibia and patella. (c-d) Reformatted CT images (c, d) reveal same lesions in tarsal, metatarsal bones and all phalanxes with residual trabeculations in talus and calcaneus.

ful lesions were operated. A bone window was created in left talus, calcaneus, cuboids, navicula, cuneiforms, tarsal bones via proper exposures. The masses were curetted and some drillings performed in the bones. Talus was extremely weak with nearly no cancellous bone present. The curetted materials were glossy yellowish lipomatous masses. They were sent to frozen section examination, which revealed benign fatty tissue. Then, the bone defects created during curettage was filled with large amount of allograft bone.

The short leg splint was applied after operation. The patient was allowed to walk with crutches but not weight bearing for 6 weeks, partial for 6 weeks. The patient's postoperative course was uneventful. She was followed up by x-rays, and full weight-bearing was allowed at the end of third month upon consolidation of the graft tissue. After 9 months the operation she fell down in home and left radial distal fracture was seen. She was treated by closed reduction, percutaneus pinning. Her control x-rays showed complete union and spontaneous healing of lipomatous cystic lesion in 12 weeks.
She complained with pain in right ankle and right proximal tibia after 2 months of radius fracture. Same procedure applied for right ankle bones and tibial lesions. All lesions were operated by curettage and grafting healed. The other asymptomatic lesions were not operated.

\section{Case 2:}

26 years old female (EP) referred to our clinic with both ankle pain and limping, without trauma, for 3 months. There was tenderness in palpation of talus, calcaneus and other ankle and foot bones. There was no additional physical examination finding such as oedema, hyperaemia or swelling. Ankle ROM was accepted as normal. The whole blood count and routine blood tests, including the sedimentation, lipid-cholesterol levels and CRP were normal. There was no history of corticosteroid or any other hormone usage. Her two plane x-rays were revealed same characteristic of lytic appearance in all the bilateral talus, calcaneus, phalanxes, tarsal and metatarsal bones. CT detected well-marginated, low-density lesions $(-84 \mathrm{H})$. The upper extremity was also affected especially hand and wrist. Her major complain was in left side that is why left talus, calcaneus and cuboids curetted and grafted. The patient allowed weight bearing at 8 weeks. Clinical and radiologic parameters showed complete consolidation.

\section{Case 3:}

52 years old male patient (AT) consulted to our clinic bilateral ankle and feet pain. He stated a sharp mild pain and limping on his left ankle 1 month ago without trauma. His two plane $\mathrm{x}$-rays revealed a wide cystic cavity with a lytic appearance causing cortical expansion in the left talus, calcaneus, all tarsal, metatarsal bones and phalanxes. There were occasional calcification and sclerosis around these lesions. There was a thin mild depressed cortex in left talus dome suspecting impaction fracture. The low-density and well-marginated lesions detected on CT. Both distal tibia and fibula have same lesions. His all blood tests were normal. The symptomatic lesions on talus, calcaneus and tarsal bones underwent curettage and grafting. The short leg walking cast applied after operation. The patient al- 


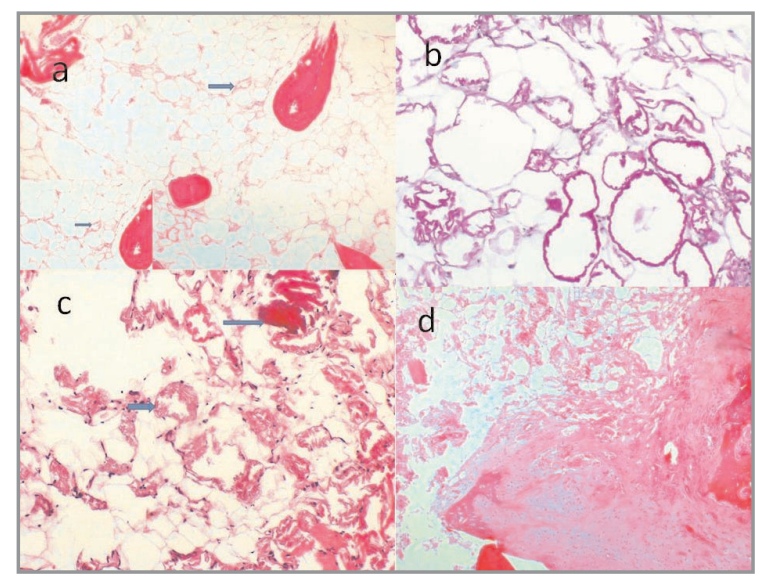

Figure 3 (a) Light photomicrograph showing the lesion consists of mature adipose tissue devoid of hematopoietic elements (Original magnification, H\&E X 50, and X 100). (b) Curetted lesion reveals an area a new bone formation (Original magnification, H\&E, X 100). (c) Lipogranulomatous change (upper arrow) and a calcification area (lower arrow) is seen. (Original magnification, H\&E, X 100). (d) Typical PASpositive lipomembranes showing lining microcysts and macrocysts in osseous lipoma (PAS, x200).

lowed to partial weight bearing with a pair of crutch. The cast removed on 6 week and full weight bearing allowed on 10 weeks. Complete consolidation observed in 14th week.

Histopathologic examination of the resected and/or curetted lesions in the bones of these patients showed areas of mature adipose tissue with some bone islands and calcification areas, which were devoid of medullary trabecular bone (Figure 3a). Thin bone trabeculae were present throughout the lesion. The definitive detailed histopathological examination of the extracted materials revealed microcystic and macrocystic changes within the fat lobules (Figure $3 b$ ). There was deposition of amorphous, anuclear, eosinophilic membrane lining the microcysts and macrocysts. The membrane stained with periodic acid-Schiff, Which is designed lipomembran (Figure 3c). Typical lipomembranous fat necrosis was also observed in three cases. These changes were diffusely observed throughout the lesion. No cellular atypia or mitoses were encountered. In some lesions, foci of fat necrosis were observed in association with foamy histiocytes and mild chronic inflammatory cells in the septae. There were foci of dystrophic calcification and areas focal reactive bone (Figure 3d). These findings are consistent with those of intraosseous lipomas with lipomembranous alterations in multiple bony involvements.

\section{DISCUSSION}

Intraosseous lipomas (IOL) are almost always seen as solitary lesions. Multiple Intraosseous lipomas (MIOL) are only case reports in the literature..$^{5-6-7}$ Clinically, IOL can present with pain but it is generally diagnosed incidentally on radiographs. ${ }^{8}$ IOL can be found in any part of any bone since fat is present in the marrow of all bones. However, the majority of these occur in the long bones and calcaneus in the lower extremity. ${ }^{3.4}$ The aetiology is not clear. Hypotheses range from primary benign neoplasm to reactive bone lesion following trauma or bone infarction. ${ }^{2,8}$ MIOL has been reported in the patients with hyperlipoproteinemia, macrodystrophia lipomatosa and as a congenital variant following autosomal pattern of inheritance. ${ }^{5,6}$ These lesions can progress to pathological fractures. ${ }^{9}$ In our three patients, both the upper and lower limb involvement was seen and there was no coexisting condition that could have predisposed to those lesions. Only one lesion accepted as healed insidious compression fracture in our three cases.

IOL have been reported that about half of the patients with an IOL are asymptomatic, and that the tumour is found incidentally. ${ }^{2,4,8,10}$ Most common complaint is pain. All our patients major complaint were pain on the talus even calcaneus and the other tarsal, metatarsal bones and phalanxes were affected.

The localization of the lesion is reported as the most frequent site is the femur ${ }^{2}$; but some authors stated that the most commonly affected bone is the calcaneus. ${ }^{3.4}$ Szendroi ${ }^{10}$, Rehani ${ }^{7}$ and Döhler ${ }^{6}$ published MIOL cases involving mainly lower extremity. However our patients represent both upper and lower extremity bone lesions. Their symptomatic lesions were in talus, calcaneus and tarsal bones. The other lesions were asymptomatic. Pathologic fractures were observed in a talus (AT) and distal radius (BB). The majority of the lipomas situated in long bones were localized in the metaphyseal area, but in phalanxes, metatarsals and metacarpals extended into the diaphyseal region. 
The most of the patients can be diagnosed by conventional $\mathrm{x}$-rays, computed tomography (CT) and MRI techniques.. IOL appears as a benign well-defined osteolytic lesion on plain radiographs with sclerotic borders in almost all cases. ${ }^{12,13}$ The lesion may mildly expand and remodel the cortex with resorption of the endosteal surface. The heavy calcification and ossification regions within its matrix are often seen. ${ }^{12,13}$ We observed radiolucent lesions in tarsal, metatarsal bones and all phalanxes with residual trabeculations. There were cortical expansion, thinning and some calcifications. The differential diagnosis includes simple cyst, aneurysmal bone cyst, non-ossifying fibroma, fibrous dysplasia, giant cell tumour, avascular necrosis and even chondroid tumours. ${ }^{2,3}$ The first patient (BB) taught us CT density is specific in IOL lesions $(-60,-110)$. We used CT for diagnosis in case 2 and 3 taking care especially fat attenuation and trabecular pattern. We believe that classic plain radiographs and lesion fat density measurement by $\mathrm{CT}$ are enough for diagnosis.

Milgram $^{2}$ described 3 stages. Stage I: radiographically there is a purely radiolucent zone with expansion of the original cortex; microscopically there are viable lipocytes, interspersed with tiny bone trabeculae. Stage II: the radiological aspect may be the same, but there are often localized calcifications; histologically, there is a mixed pattern of viable and necrotic lipocytes besides central calcification and ossification. Stage III: radiographically there is considerable ossification around the calcified fat of the outer rim of the lesion; histologically there is complete fat necrosis. He also stated IOL may progress from stage I to stage II or III. We observed different stages together in our patients.

We observed lipomembranes stained histochemically by PAS in some lesions. This lipomembranous alteration is necrosis of adipose tissue characterized by formation of pseudocystic cavities lined by eosinophilic membranes and known as membranocystic or lipomembranous fat necrosis. Chow and Lee reported these as pathological changes in intraosseous lipomas are secondary to ischemia caused by increased intramedullary pressure and the growth of the tumour with compromise of blood supply at the capillary level. ${ }^{14}$

Although these tumours are considered benign lesi- ons, secondary malignancy risk is reported for IOL. ${ }^{2,8,15}$ It is not clear what causes this transformation and how, yet the possibility of malignant transformation should be taken into consideration. We informed the patients about this possibility and advised each 6 month revisit.

The surgical treatment is controversial. Some authors have stated that this lesion belongs to the "leave me alone" group of bony lesions and that no treatment is necessary. ${ }^{15}$ Some authors feel that in asymptomatic cases with no sign of an impending fracture, nonoperative treatment with clinical and radiographic follow-up is a good choice.$^{2,8,16} \mathrm{Radl}$ et al. published that phenolization has no benefit in treatment of IOL. ${ }^{17}$ But generally symptomatic tumours and in cases with impending fracture, persistent pain, the need for a pathological diagnosis, or the need to decrease the risk of malignant transformation, operative intervention is the recommended treatment. Curettage with or without bone grafting is the treatment of choice. We filled the lesions with corticospongious allograft after meticulous curettage seeing there were large cavities in symptomatic lesions our patients. Recurrences are reported as very rare. ${ }^{18}$ We followed the patients about 2 years and did not detect any relapse.

The exact aetiology of this lesion is unknown. The published hypotheses are primary benign neoplasm $^{19,20}$ and a reactive bone lesion following trauma or bone infarct..$^{20}$ The hyperlipoproteinemia has been suggested to be a possible reason for the intraosseous lipoma. ${ }^{5,6}$ However authors believe that IOL is a benign fatty tumour by nature., There was no lipid abnormality and any palpated lipoma mass in our patients. We agree with common primary benign fatty tumour theory.

\section{REFERENCES}

1. Buckley SL, Burkus JK. Intraosseous lipoma of the ilium. A case report. Clin Orthop 228: 297-301, 1988.

2. Milgram JW. Intraosseous lipomas: A clinicopathologic study of 66 cases. Clin Orthop 231: 277-302, 1988.

3. Campbell RS, Grainger AJ, Mangham DC, et al. Intraosseous lipoma: report of 35 new cases and a review of the literature. Skeletal Radiol 2: 209-222, 2003. 
4. Kapukaya A, Subasi M, Dabak N, Ozkul E. Osseous lipoma: Eleven new cases and review of the literature. Acta Orthop Belg 72: 603-614, 2006.

5. Freiberg RA, Air GW, Glueck CJ, et al. Multiple intraosseous lipomas with type-IV hyperlipoproteinemia. A case report. J Bone Joint Surg Am 56: 1729-1732, 1974.

6. Döhler R, Poser HL, Harms D, Wiedemann HR. Systemic lipomatosis of bone. A case report. J Bone Joint Surg Br 64: 84-87, 1982.

7. Rehani $B$, Wissman R Multiple intraosseous lipomatosis: A case report. Cases J 2: 7399, 2009.

8. Milgram JW. Intraosseus lipomas: Radiologic and Pathologic manifestations. Radiology 167: 155-160, 1988.

9. Szendroi M, Karlinger K, Gonda A: Intraosseous lipomatosis. Acase report. J Bone Joint Surg Br 73: 109112, 1991.

10. Goto T, Kojima T, Lijima T, et al. Intraosseous lipoma : a clinical study of 12 patients. J Orthop Sci 7: 274280, 2002.

11. Propeck T, Bullard MA, Lin J, et al. Radiologic-pathologic correlation of intraosseous lipomas. AJR Am J Roentgenol 175: 673-678, 2000.

12. Leeson MC, Kay D, Smith BS. Intraosseous lipoma. Clin Orthop Relat Res 181: 186- 190, 1983.

13. Hirata M, Kusuzaki K, Hirasawa Y. Eleven cases of intraosseous lipoma of the calcaneus. Anticancer Res 21: 4099-4103, 2001.

14. Chow LTC, Lee KC. Intraosseous lipoma: a clinicopathologic study of nine cases. Am J Surg Pathol 16: 401 $-410,1992$.

15. Milgram JW. Malignant transformation in bone lipomas. Skeletal Radiol 19: 347-352, 1990.
16. Kozlowski K,Welshman R. What is it? Intraosseous lipoma in 13-year-old boy. Br J Radiol 64: 855-856, 1991.

17. Radl R, Leithner A, Machacek F, et al. Intraosseous lipoma: retrospective analysis of 29 patients. Int Orthop 28: 374-378, 2004.

18. Stukenborg-Colsman C, Wülker N, Wirth CJ. Cystic bone lesions of the calcaneus and the talus : report of five cases. Foot Ankle Surg 5: 33-38, 1999.

19. Goldman AB, Marcove RC, Huvos AG, Smith J. Case report 280: Intraosseous lipoma of the tibia. SkeletalRadiol 12: 209-212, 1984.

20. Unni K. Lipoma and liposarcoma. In: Unni K (ed) Dahlin's bone tumors: general aspects and data on 11087 cases. Philadelphia, Lippincott-Raven, 1996: 349353.

\section{Correspondence}

Dr. Ali Murat KALENDER

Kahramanmaraş Sütçü İmam Üniversitesi

Ortopedi Anabilim Dalı

46050, Kahramanmaraş / TURKEY

Tel: (+90.344) 2212337 / 139

Fax: (+90.344) 2212371

kalenderalimurat@hotmail.com 